\title{
Analisis Sikap Tanggung Jawab Siswa dalam Proses Pembelajaran Daring Melalui Aplikasi Whatsapp
}

\author{
The Analysis of Student Responsibilities on Online Learning with Whatsapp \\ Application
}

\author{
Rohmatus Syafi'ah ${ }^{1}$, Wahyu Kurnia Sari ${ }^{2^{*}}$ \\ ${ }^{1}$ Program Studi Pendidikan IPA, Fakultas Sosial dan Humaniora, Universitas Bhinneka \\ PGRI, ${ }^{2}$ Program Studi PGSD, Fakultas Sosial dan Humaniora, Universitas Bhinneka \\ PGRI \\ e-mail: ${ }^{1}$ syafiahzainul@gmail.com ${ }^{2}$ wahyukurniasari016@gmail.com*
}

\begin{abstract}
On the covid-19 pandemic, all of the education systems are conducted online. In online learning, the $4^{\text {th }}$-grade students of SDN Tegalrejo Tulungagung use Whatsapp. Online learning using Whatsapp refers to the 2013 curriculum, which is several sub-theme into a theme. The 2013 curriculum has some attitudes which are needed to learn. One of them is a responsible attitude. This study's responsibility attitude consists of two indicators: 1) fulfill its obligations, and 2) self-discipline. This research was conducted in grade 4 SD Negeri Tegalrejo Tulungagung. The research design in this study was qualitative research with a descriptive system. The data collecting method of this study were questionnaire, interview, and documentation. Data analysis in this study used transcripts of the results of questionnaires and interviews, data reduction, data interpretation, and triangulation. This study's work from students' questionnaire shown students' responsibility attitude in online learning using WhatsApp on Theme 9 Sub-theme 3 Lesson 3 get a percentage of $91 \%$; it is classified as "very good."
\end{abstract}

Keywords: Responsibility Attitudes, Online Learning Process Using Whatsapp

\section{A. Pendahuluan}

Dunia saat ini khususnya Indonesia sedang menghadapi wabah besar yang dikenal dengan Virus Corona 2019 (Covid-19). Covid-19 adalah SARS-CoV yang menimbulkan penyakit, dimana penderita akan mengalami gejala antara lain (1)infeksi pernafasan, (2) demam, (3) sakit kepala, (4) batuk, (5) nyeri oto dan gejala lainnya (Wulandari dkk, 2020). Pandemi Covid-19 berdampak pada semua aspek dunia, maka dari itu pemerintah menerapkan sistem pembatasan sosial (social distancing) untuk menghidari dan memutus rantai penyebarannya (Telaumbanua, 2020). Sejalan dengan pernyataan tersebut Yunus \& Rezki (2020) menyatakan bahwa salah satu permasalahan yang tidak dapat disepelekan saat ini adalah pandemi covid-19, dimana salah satu dampaknya adalah penggantian sistem pembelajaran yang sudah ada diganti dengan sistem pembelajaran daring dalam sektor pendidikan. 
Pembelajaran daring merupakan pembelajaran yang menggunakan teknologi internet. Rimbarizky \& Susilo, (2017) menyatakan bahwa pembelajaran daring adalah pembelajaran yang dilakukan tidak dengan bertatap muka secara langsung melainkan melalui aplikasi yang telah tersedia. Pelaksanaan pembelajaran daring tidak terbatas ruang dan waktu selama terhubung dengan internet (Laelasari, dkk., 2016). Karakteristik pembelajaran daring antara lain waktu dan tempat yang tidak terbatas, penyajian materi ajar dalam bentuk teks, grafik, dan elemen multimedia lain, komunikasi melalui ruangan chating, forum diskusi, tatap muka secara maya melalui video conferencing yang mudah diperbarui, pembelajaran dapat berbasis CD-ROM, sumber belajar luas melalui internet, bentuk komunikasi formal dan informal, dsb (Rosali et al., 2020).

Perangkat mobile seperti komputer, laptop, iphone, tablet, dan android atau smartphone diperlukan dalam pelaksanaan pembelajaran daring (Sadikin \& Hamidah, 2020). Salah satu aplikasi modern dalam aplikasi smartphone yang dapat mempermudah interaksi antar orang satu dengan yang lainnya dalam menyampaikan pesan ialah melalui aplikasi WhatsApp. WhatsApp mempunyai fungsi dalam berbagai hal. Fungsi WhatsApp diantaranya sebagai fungsi personal dan grup chat, dimana kita dapat berbagi berbagai hal bukan hanya dengan seorang saja namun juga mempermudah kita berbagi dengan banyak orang seperti grup keluarga maupun teman satu kelas serta sebagai media pendidikan (Sukrillah, 2017). Selanjutnya (Naldi, 2020) menyatakan bahwa grup WhatsApp dapat menampung hingga 256 orang dalam satu grup yang didalamnya dapat berinteraksi dengan membagikan pesan, foto, video dan masih banyak lagi. Dalam menghadapi wabah covid-19, pelaksanaan pendidikan kita saat ini tetap mengacu pada kurikulum yang ada.

Wawancara awal pada tanggal 10 Mei 2020 yang dilakukan peneliti pada guru kelas IV SD Negeri Tegalrejo dengan cara datang langsung ke rumah guru kelas IV dan bertatap muka secara langsung menyatakan bahwa dalam menghadapi wabah covid-19 ini SD Negeri Tegalrejo khususnya kelas IV melaksanakan pembelajaran secara daring dengan memanfaatkan grup WhatsApp dimana didalamnya antara guru dan banyak siswa dapat berinteraksi tanpa tatap muka. Selain itu, grup WhatsApp dapat digunakan untuk integrasi antara siswa dan guru dalam waktu nyata(Prajana et al., 2018). WhatsApp merupakan salah satu aplikasi pada Hand Phone (HP) android, bisa diunduh kapan saja dan dimana saja selama terhubung koneksi internet. Fungsi WhatsApp diantaranya sebagai fungsi personal dan grup chat, dimana kita dapat berbagi berbagai hal bukan hanya dengan seorang saja namun juga mempermudah kita berbagi dengan banyak orang seperti grup keluarga maupun teman satu kelas serta sebagai media pendidikan (Sukrillah et al., 2018). WhatsApp mempunyai fitu-fitur yang dapat digunakan dalam pembelajaran daring diantaranya berupa pesan singkat, pesan suara (voice note), gambar (image), video, dan dokumen file berupa word, ppt, atau pdf (Nazri \& Maria, 2020). Dalam menghadapi wabah covid-19, pelaksanaan pendidikan kita saat ini tetap mengacu pada kurikulum yang ada. Hal ini sejalan dengan (Gheytasi et al., 2015) yang menyatakan bahwa siswa banyak berinteraksi dengan HP sehingga 
pembelajaran dengan memnggunakan HP akan lebih memudahkan siswa dalam memahami teks bacaan.

Pendidikan jenjang Sekolah Dasar (SD) saat ini menerapkan kurikulum 2013. Kurikulum adalah suatu perangkat dan acuan dalam proses pembelajaran yang didalamnya berisi aktifitas yang nantinya dilakukan siswa yang bertujuan untuk mencapai suatu pembelajaran tertentu dan tujuan pendidikan secara umum (Kurinasih, 2014). Pembelajaran daring yang berlangsung antara guru dan siswa kelas IV SD Negeri Tegalrejo tetap menerapkan konsep pembelajaran kurikulum 2013 yaitu pembelajaran tematik, dimana salah satunya terdapat materi tema 9 Subtema 3 Pembelajaran 3 yang memuat dua mata pelajaran yakni mata pelajaran IPA dan Bahasa Indonesia pada semester II

(Mulyasa, 2013) menyatakan bahwa melalui pengembangan kurikulum 2013 maka akan menghasilkan manusia yang kreatif dan inovatif serta produktif dan aktif melalui penguatan dalam penilaian sikap, keterampilan dan pengetahuan. Sasaran pengembangan sikap dalam kurikulum 2013 mencakup sikap spiritual dan sikap sosial. Salah satu sasaran dalam ranah sikap sosial yang diterapkan pada kurikulum 2013 adalah sikap tanggung jawab. Sikap tanggung jawab siswa yaitu perilaku siswa secara terencana untuk melaksanaan tugas dan kewajibannya. Salah satu kecakapan hidup yang seyogyanya dimiliki oleh guru maupun siswa di abad 21 adalah sikap tanggung jawab (Rakhmawati, 2017).

Menurut (Zain, 2006) pembebanan tanggung jawab jawab belajar pada seseorang akan mampu meningkatkan kemampuan berpikir dan mengembangkan bakatnya dengan belajar sesuai dengan harapan lingkungan sekitar maupun diri sendiri. Penelitian yang relevan terkait sikap tanggung jawab diantaranya penelitian (Suryadewi, 2018) dengan judul "Analisis sikap tanggung jawab belajar siswa kelas IV SD Negeri 1 Gebang kecamatan Pakel kabupaten Tulungagung tahun ajaran 2018/2019”. Penelitian tersebut menunjukkan bahwa sikap tanggung jawab siswa kelas IV SD Negeri 1 Gebang pada indikator disiplin diri di dalam kelas dengan kriteria cukup dan disiplin diri saat pulang sekolah kriteria baik. Perbedaan penelitian relevan tersebut di atas dengan penelitian yang akan dilakukan peneliti adalah pada penelitian relevan sikap tanggung jawab yang diteliti luas mencakup sikap tanggung jawab pada saat di luar maupun di dalam proses pembelajaran, sedangkan pada penelitian ini, peneliti fokus pada sikap tanggung jawab anak dalam proses pembelajaran daring (dalam jaringan). Rumusan masalah yanga akan dijawab adalah bagaimana sikap tanggung jawab siswa dalam proses pembelajaran daring (dalam jaringan) melalui aplikasi WhatsApp pada tema 9 kelas IV SD Negeri Tegalrejo tahun pelajaran 2019/2020.

\section{B. Metode}

Pendekatan yang digunakan dalam penelitain ini adalah kualitatif dengan jenis deskriptif. Jenis penelitian yang akan digunakan dalam penelitian ini adalah jenis deskriptif. Subjek pada penelitian ini adalah siswa kelas IV SD Negeri Tegalrejo yang berjumlah 8 siswa dengan jumlah laki-laki sebanyak 4 dan perempuan sebanyak 4 . 
Penelitian ini dilakukan selama kurun waktu 3 minggu pada tahun ajaran 2019/2020 tepatnya pada semester genap. Instrumen penelitian yang digunakan dalam penelitian meliputi lembar angket yang nantinya diberikan ke siswa, lembar wawancara yang nanti ditujukan kepada siswa sebagai narasumber primer dan guru sebagai narasumber skunder serta dokumentasi. Analisis data dalam penelitian ini menggunakan transkrip hasil angket dan wawancara, reduksi data, interpretasi data, dan triangulasi. Penghitungan persentase, peneliti menggunakan rumus sebagai berikut:

$$
\text { Presentase }(\%)=\frac{\text { jumlah skor yang diperoleh }}{\text { jumlah skor ideal }} \times 100 \%
$$

Tabel 1.Kriteria Nilai Angket Siswa

\begin{tabular}{cc}
\hline Angka & Kriteria \\
\hline $0 \%-19,99 \%$ & Sangat buruk \\
\hline $20 \%-39,99 \%$ & Kurang baik \\
\hline $40 \%-59,99 \%$ & Cukup baik \\
\hline $60 \%-79,99 \%$ & Baik \\
\hline $80 \%-100 \%$ & Sangat baik \\
& (Romika \& Amalia, 2014) \\
\hline
\end{tabular}

\section{Hasil dan Pembahasan}

Berikut ini merupakan kisi-kisi angket yang digunakan untuk mengetahui sikap tanggung jawab siswa:

Tabel 2. Kisi-Kisi Angket Siswa

\begin{tabular}{|c|c|c|c|c|}
\hline No. & Indikator & Pernyataan & $\begin{array}{l}\text { No } \\
\text { Item }\end{array}$ & $\begin{array}{l}\text { Jumlah } \\
\text { Item }\end{array}$ \\
\hline \multirow{4}{*}{1} & \multirow{4}{*}{$\begin{array}{l}\text { Memenuhi } \\
\text { Kewajiban } \\
\text { Diri }\end{array}$} & $\begin{array}{l}\text { Siswa mengikuti intruksi guru untuk membaca } \\
\text { materi pada buku paket cerdas tangkas tema } 9 \\
\text { subtema } 3 \text { pembelajaran } 3 \text {. }\end{array}$ & 1 & 1 \\
\hline & & $\begin{array}{l}\text { Dalam proses pembelajaran daring, Siswa } \\
\text { menerima tugas daring yang telah diberikan guru } \\
\text { untuk membuat poster. }\end{array}$ & 2 & 1 \\
\hline & & $\begin{array}{l}\text { Siswa mengikuti instruksi dari guru untuk } \\
\text { membuat poster dengan tema "menjaga } \\
\text { keselamatan bumi" melalui grup WhatsApp. }\end{array}$ & 3 & 1 \\
\hline & & Siswa mengerjakan tugas di rumah & 4 & 1 \\
\hline \multirow[b]{2}{*}{2} & \multirow[b]{2}{*}{$\begin{array}{l}\text { Disiplin } \\
\text { Diri }\end{array}$} & $\begin{array}{l}\text { Siswa menerima tugas daring yang telah diberikan } \\
\text { guru sesuai hari dan waktu saat pemberian tugas } \\
\text { dari guru. }\end{array}$ & 5 & 1 \\
\hline & & $\begin{array}{l}\text { Siswa mengerjakan tugas membuat poster sesuai } \\
\text { jadwal yang telah ditentukan guru yakni } \\
\text { pengumpulan tugas jam tujuh pagi sampai dua } \\
\text { belas siang. Sumber: Adaptasi (Suryadewi, 2018) }\end{array}$ & 6 & 1 \\
\hline
\end{tabular}


Berdasarkan hasil penelitian diperoleh data sebagaimana terlampir pada tabel berikut:

Tabel 3. Deskripsi Data Hasil Angket Siswa Kelas IV SD Negeri Tegalrejo

\begin{tabular}{|c|c|c|c|c|c|c|c|c|c|}
\hline \multirow[t]{3}{*}{ No. } & \multirow[t]{3}{*}{$\begin{array}{l}\text { Nama } \\
\text { Siswa }\end{array}$} & \multicolumn{8}{|c|}{$\begin{array}{c}\text { Tanggung Jawab Siswa Ddalam Proses Pembelajaran Daring Melalui } \\
\text { aplikasi Whatsapp Pada Tema } 9 \text { Subtema } 3 \text { Pembelajaran } 3\end{array}$} \\
\hline & & \multicolumn{4}{|c|}{$\begin{array}{l}\text { INDIKATOR } 1 \\
\text { (Memenuhi } \\
\text { kewajiban diri } \\
\text { membuat poster) }\end{array}$} & \multicolumn{2}{|c|}{$\begin{array}{c}\text { INDIKATOR } 2 \\
\text { (Disiplin diri dalam } \\
\text { pengumpulan tugas } \\
\text { membuat poster } \\
\text { jam } 07.00-12.00\end{array}$} & \multirow[t]{2}{*}{$\begin{array}{c}\text { Jumlah } \\
\text { Skor } \\
\text { yang } \\
\text { diperoleh }\end{array}$} & \multirow[t]{2}{*}{$\begin{array}{c}\text { Presentase } \\
\%\end{array}$} \\
\hline & & 1 & 2 & 3 & 4 & 5 & 6 & & \\
\hline 1 & B.R & 5 & 5 & 5 & 4 & 4 & 2 & 25 & $83 \%$ \\
\hline 2 & C.C & 5 & 5 & 4 & 4 & 4 & 5 & 27 & $90 \%$ \\
\hline 3 & I.R & 5 & 5 & 5 & 4 & 4 & 5 & 29 & $97 \%$ \\
\hline 4 & M.V & 5 & 5 & 4 & 5 & 5 & 5 & 29 & $97 \%$ \\
\hline 5 & M.C & 5 & 5 & 5 & 4 & 4 & 5 & 28 & $93 \%$ \\
\hline 6 & M.A & 5 & 4 & 4 & 4 & 5 & 5 & 27 & $90 \%$ \\
\hline 7 & R.N & 5 & 4 & 5 & 4 & 5 & 4 & 27 & $90 \%$ \\
\hline 8 & R.F & 5 & 5 & 5 & 1 & 4 & 4 & 20 & $67 \%$ \\
\hline \multicolumn{8}{|c|}{ Total } & 212 & $707 \%$ \\
\hline \multicolumn{8}{|c|}{ Rata-rata } & 26 & $88 \%$ \\
\hline
\end{tabular}

Berdasarkan hasil angket dan wawancara yang telah didapat peneliti menunjukkan bahwa sikap tanggung jawab siswa kelas IV SD Negeri Tegalrejo sudah sangat baik sebagai seorang siswa selama proses pembelajaran daring. Bentuk tanggung jawab dalam pembelajaran daring dapat diukur dengan dua indikator, yakni tanggung jawab memenuhi kewajiban diri untuk membuat poster dan tanggung jawab disiplin diri dalam pengumpulan pembuatan poster dengan jangka waktu jam 07.00-12.00. Dari hasil perhitungan angket yang telah diisi siswa menunjukkan bahwa pada indikator 1 (memenuhi kewajiban diri) dan indikator 2 (disiplin diri) menunjukkan bahwa 1 siswa mendapat persentase $67 \%$ dengan kategori baik, 3 siswa mendapat persentase $89 \%$ kategori sangat baik, 1 siswa mendapat persentase $83 \%$ kategori sangat baik, 3 siswa mendapat persentase $90 \%$ dengan kategori sangat baik, 1 siswa mendapat persentase 93\% dengan kategori sangat baik, dan 2 siswa mendapat persentase 97\% dengan kategori sangat baik. Di bawah ini merupakan contoh dokumentasi pembelajaran daring siswa terkait sikap tanggung jawab siswa dalam menyelesaikan tugas yang diberikan oleh guru. 


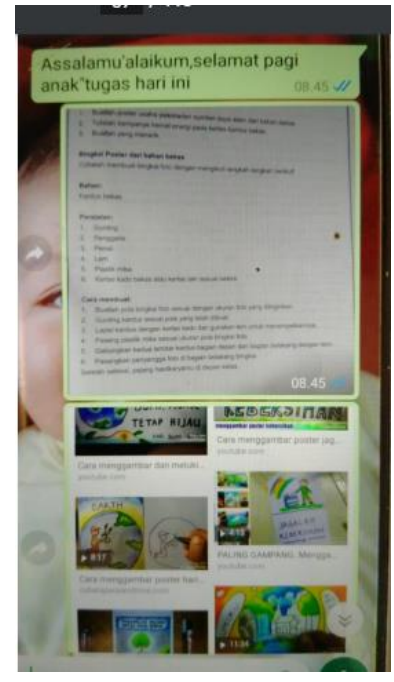

Gambar 1. Pemberian Tugas Kelas IV SDN Tegalrejo (sumber: Dokumen Pribadi Nur Farida, Mei 2020)
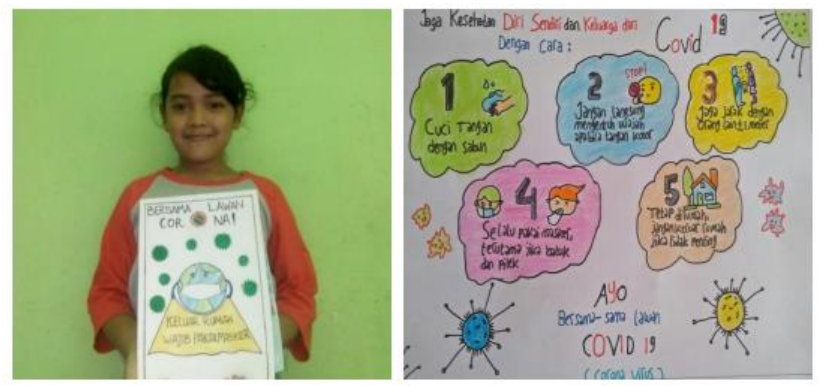

Gambar 2. Contoh Hasil Tugas Siswa yang Dikirim Via WhatsApp (sumber: Dokumen Pribadi Nur Farida, Mei 2020)

Hasil angket siswa pada tabel 3 menunjukkan bahwa ketercapaian tanggung jawab siswa dalam proses pembelajaran daring melalui aplikasi whatsapp pada tema 9 yang mencakup indikator 1 (memenuhi kewajiban diri membuat poster) dan indikator 2 (disiplin diri dalam pengumpulan tugas membuat poster dengan jangka waktu jam 07.00 - 12.00) mendapat nilai skor rata-rata 26 dengan persentase $88 \%$ yang menempati kategori "sangat baik". Hal ini sesuai dengan penelitian yang dilakukan oleh (Utami \& Utami, 2020) yang menyatakan bahwa pembelajaran daring melalui whatsapp grup dapat meningkatkan partisipasi siswa dalam pembelajaran daring sehingga proses pembelajaran dapat berlangsung dengan baik sesuai yang diharapkan. Selanjutnya, data hasil perhitungan angket siswa diperkuat dengan hasil wawancara yang dilakukan dengan siswa. Data hasil wawancara memperoleh suara terbanyak siswa menunjukkan sikap tanggung jawab dalam proses pembelajaran daring melalui aplikasi whatsapp pada tema 9, subtema 3, pembelajaran 3 pada indikator 1 (memenuhi kewajiban diri) dalam mengikuti intruksi guru untuk membuat poster dan juga bertanggunng jawab 
pada indikator 2 (disiplin diri) dalam pengumpulan pembuatan poster dengan jangka waktu pukul $07.00 \mathrm{~s} / \mathrm{d} 12.00$.

Hasil penelitian menunjukkan bahwa siswa kelas IV di SDN Tegalrejo Tulungagung telah memiliki sikap tanggung jawab dengan sangat baik hal ini tercermin dari kesesuaian dengan indikator sikap tanggung jawab yang dikemukakan oleh (Ermral, 2017) yaitu memenuhi kewajiban diri dan disiplin diri. Senada dengan (Suryadewi, 2018) yang menyatakan bahwa sikap tanggung jawab siswa kelas IV SD Negeri 1 Gebang ketika berangkat sekolah adalah dengan kriteria cukup, dimana siswa lebih banyak berangkat sekolah dengan 5 tepat waktu, selain itu sikap tanggung jawab siswa ketika berada di kelas dengan kriteria cukup dimana sejumlah lebih pasif, rame dalam pembelajaran dan sedikit yang memperhatikan guru serta sikap tanggung jawab belajar siswa ketika pulang sekolah dengan hasil kriteria baik, dimana ketika pulang sekolah siswa langsung pulang dan bergegas pergi bimbingan belajar.

\section{Simpulan}

Berdasarkan hasil penelitian dan pembahasan yang telah dilaksanakan untuk mengetahui sikap tanggung jawab siswa dalam proses pembelajaran daring melalui aplikasi WhatsApp pada tema 9, subtema 3, pembelajaran 3 kelas IV SD Negeri Tegalrejo tahun pelajaran 2019/2020 menunjukkan bahwa sikap tanggung jawab siswa kelas IV SD Negeri tegalrejo tulungagung sudah tergolong sangat baik. Hal ini terlihat pada saat siswa kelas IV SD Negeri tegalrejo tulungagung sudah dapat menjalankan aspek-aspek dari tanggung jawab yakni a) memenuhi kewajiban diri dan b) disiplin diri.

\section{Daftar Rujukan}

Ermral, E. (2017). Pengantar Teori dan Metodologi Pelatihan Fisik. Journal of Chemical Information and Modeling.

Gheytasi, M., Azizifar, A., \& Gowhary, H. (2015). The Effect of Smartphone on the Reading Comprehension Proficiency of Iranian EFL Learners. Procedia - Social and Behavioral Sciences. https://doi.org/10.1016/j.sbspro.2015.07.510

Kurinasih, dan S. (2014). Implementasi Kurikulum 2013 Konsep \& Penerapan. Kata Pena.

Mulyasa. (2013). Pengembangan dan Implementasi kurikulum 2013. Bandung: Remaja Rosadakarya.

Naldi, E. W. (2020). PEMANFAATAN WHATSAPP GROUP KELAS DALAM PENYEBARAN INFORMASI PEMBELAJARAN DI SEKOLAH MENENGAH ATAS (SMA) NEGERI 1 KAMPAR TIMUR.

Nazri \& Maria. (2020). Media Alternatif Whatsapp (WA) Mengatasi Permasalahan Pembelajaran pada Situasi Pendemi Covid 19 di Kelas PGMI Semester IV. AtThullab: Jurnal Pendidikan Guru Madrasah Ibtidaiyah, 4. https://journalfai.unisla.ac.id/index.php/at-thulab/article/view/215/pdf

Prajana, A., Ilmiah, P., Fauzi, A. A. R., Studi, P., Komunikasi, I., Komunikasi, F., 
Informatika, D. A. N., Surakarta, U. M., Buchenscheit, A., Könings, B., Neubert, A., Schaub, F., Schneider, M., Kargl, F., Putri, N. E., Iskandar, D., Anwar, N., Riadi, I., Junaida, D. S., ... Zuliarso, E. (2018). Pemanfaatan Aplikasi Whatsapp dalam Media Pembelajaran di UIN Ar-Raniry Banda Aceh. Cyberspace: Jurnal Pendidikan Teknologi Informasi.

Rakhmawati, D. (2017). Konselor Sekolah Abad 21: Tantangan Dan Peluang. Jurnal Konseling GUSJIGANG.

Romika, \& Amalia, Y. (2014). Analisis Kemampuan Pemecahan Masalah Matematika siswa pada materi bangun ruang sisi datar dengan teori van hielle. Jurnal Nina Gogik.

Rosali, E. S., Pendidikan, J., \& Universitas, G. (2020). Aktifitas Pembelajaran Daring Pada Masa Pandemi Covid-19 Di Jurusan Pendidikan Geografi Universitas Siliwangi Tasikmalaya. Geography Science Education Journal (GEOSEE.

Sadikin, A., \& Hamidah, A. (2020). Pembelajaran Daring di Tengah Wabah Covid-19. Biosilico. https://doi.org/10.22437/bio.v6i2.9759

Sukrillah, A., Ratnamulyani, I. A., \& Kusumadinata, A. A. (2018). PEMANFAATAN MEDIA SOSIAL MELALUI WHATSAPP GROUP FEI SEBAGAI SARANA KOMUNIKASI. JURNAL KOMUNIKATIO. https://doi.org/10.30997/jk.v3i2.919

Suryadewi. (2018). Analisis Sikap Tanggung jawab Belajar Siswa Kelas IV SDN1 Gebang Kecamatan Pakel Kabupaten Tulungagung Tahun Ajaran 2018/2019.

Utami, S., \& Utami, P. (2020). Penggunaan Whatsapp Group dan Google Classroom untuk Meningkatkan Partisipasi dan Hasil Belajar Peserta Didik Teknik Audio Video. Elinvo (Electronics, Informatics, and Vocational Education). https://doi.org/10.21831/elinvo.v5i1.34254

Zain, S. B. D. dan A. (2006). Strategi Belajar Mengajar. Jakarta: PT Rineka Cipta. Syaiful Bahri Djamarah Dan Aswan Zain. 